\title{
Experimental Investigation of Self Curing Concrete using Polyethylene Glycol
}

\author{
L. Kalaivani \\ Assistant Professor \\ Dept. of Civil Engineering, \\ Mookambigai College of Engineering, \\ Kalamavur,Pudukkottai .
}

\author{
I. Santhiyaraj, A. Robin, S. Lochana Suganthi, \\ T. Siva Santhi \\ Student, \\ Dept. Of Civil Engineering, \\ Mookambigai College of Engineering, \\ Kalamavur, Pudukkottai
}

\begin{abstract}
The aim of this investigation is to study the strength and durability properties of concrete using water soluble polyethylene glycol as self curing agent. The function of self curing agent is to reduce the water evaporation from concrete. The use of self curing admixtures is very important from the point of view that water resources are getting valuable every day. Polyethylene glycol in $1 \%, 1.5 \%$ and $2 \%$ place using concrete (i.e; each $1 \mathrm{~m}^{3}$ of concrete required about $3 \mathrm{~m}^{3}$ of water for construction. Most of which is for curing Concrete are made up of $\mathbf{M}_{20}$ grade mix and tested for its compressive strength test, split tensile test and flexure test up to 7, 14 \& 28 days of age and compared with conventional concrete.
\end{abstract}

Key Word: Self-curing concrete, Self-curing agent, Polyethylene Glycol (PEG-400), Water retention, Compressive strength, Workability, Saving of water.

\section{INTRODUCTION}

Concrete has been the most versatile material used in the construction industry. It is the second most consumed material in the world due to its high compressive strength and durability, which is the mixture of cement, fine aggregate, coarse aggregate and water needs curing to achieve required strength. When cement is added to water, hydration reaction takes place and this hydration process is necessary for hardening of concrete.

Curing is the process to avoid moisture content deficiency from concrete during the hydration process. Effect from curing has a strong influence on the properties of hardened concrete such as it will increase the durability, strength, volume stability, abrasion resistance, impermeability and resistance to freezing and thawing. If water is not provided then shrinkage of concrete takes place which results in cracking. Furthermore, unexpected shrinkage and temperature cracks can reduce the strength, durability, and serviceability of the concrete.

Practically good curing of concrete is not achievable in many cases due to unavailability of suitable quality of water and many other practical difficulties. During the last two decades, concrete technology has been undergoing rapid Improvements. With conventional ingredients it is possible to design reasonably good fast track concrete mixture using admixtures. Internally cured concrete can be achieved by adding Self Curing Agents.

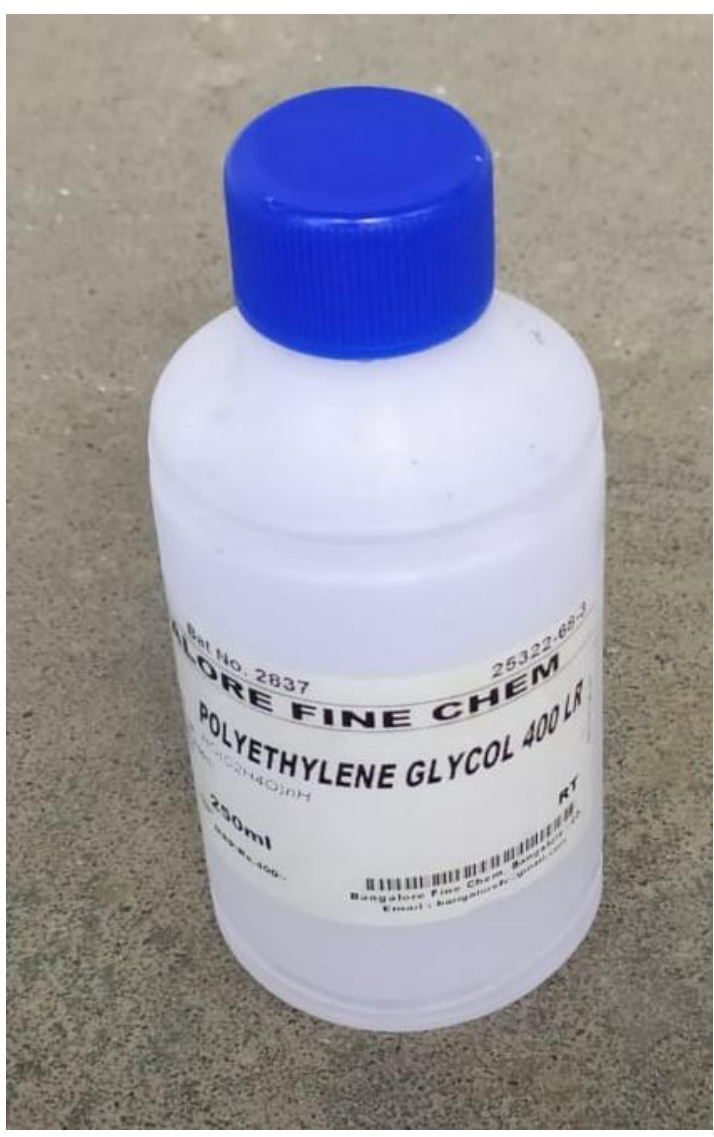

2. OBJECTIVE AND SCOPE

The main objective of our project is to reduce the usage of $\mathrm{H}_{2} \mathrm{O}$ in concrete at that same time.

$>$ It will easy to workability to use then it is also increase the strength.

\section{METHODOLOGY}

- $\quad$ Selection of materials

- Testing of materials

- $\quad$ Concrete mix design

- Testing of properties of fresh concrete(slum cone test)

- Preparation of test specimen

- Testing of properties of hardened concrete test(compressive strength, tensile stress)

- Conclusion 


\section{MATERIALS}

\subsection{CEMENT}

Ordinary Portland cement of 43 grade conforming to IS8112-1989 is used for these experiment. The physical properties of cement is shown in the table 1 .

\begin{tabular}{|l|l|c|}
\hline SI.NO & Physical properties & Values \\
\hline 1. & Specific gravity & 3.65 \\
\hline 2. & Fineness in $(\%)$ & 3.46 \\
\hline 3. & Normal consistency & 21.56 \\
\hline 4. & Initial setting time & $30 \mathrm{~min}$ \\
\hline 5. & Final setting time & $650 \mathrm{~min}$ \\
\hline
\end{tabular}

\subsection{SAND}

Natural river sand from cauvery river bed near Trichy, Tamilnadu classified under zone III is used in this experiment. Physical properties of fine aggregate is shown in the table.2.

\begin{tabular}{|l|l|c|}
\hline SI.NO & Physical properties & Values \\
\hline 1. & Specific gravity & 2.65 \\
\hline 2. & Fineness modulus & 3.17 \\
\hline
\end{tabular}

Table 2.Physical properties of sand

\subsection{Coarse aggregate}

The size of the aggregate, particle shape, color, surface texture, density, impurity all of which have an influence on the durability of concrete should conform to IS:2386 (part-III).

\begin{tabular}{|l|l|l|}
\hline SI.NO & Physical properties & Values \\
\hline 1 & Specific gravity & 2.95 \\
\hline 2 & Water Absorbtion & $1.5 \%$ \\
\hline 3 & Impact & $19.5 \%$ \\
\hline 4 & Abrasion & 40 \\
\hline 5 & Flakiness index & 15.64 \\
\hline 6 & Elongation index & 55.84 \\
\hline 7 & Crushing & 22.85 \\
\hline
\end{tabular}

Table 3 Physical properties of coarse aggregate

\subsection{POLYETHYLENE GLYCOL}

Polyethylene glycol is a condensation polymer of ethylene oxide and water with the general formula $\mathrm{H}(\mathrm{OCH}$ $2 \mathrm{CH} 2) \mathrm{nOH}$, where $\mathrm{n}$ is the average number of repeating oxyethylene groups typically from 4 to about 180 . The abbreviation (PEG) is termed in combination with a numeric suffix which indicates the average molecular weights. One common feature of PEG appears to be the water-soluble nature. Polyethylene glycol is non-toxic, odorless, neutral, lubricating, non-volatile and non-irritating and is used in a variety of pharmaceuticals

Table 4. physical properties of polyethylene glycol.

\begin{tabular}{|l|l|l|}
\hline S1.No. & DESCRIPTION & PROPERTIES \\
\hline 1. & $\begin{array}{l}\text { MOLECULAR } \\
\text { WEIGHT }\end{array}$ & 400 \\
\hline 2. & APPEARANCE & CLEAR FLUID \\
\hline 3 & MOISTURE & $0.2 \%$ \\
\hline 4 & $\mathrm{pH}$ & 6 \\
\hline 5 & SPECIFIC GRAVITY & 1.2 \\
\hline
\end{tabular}

\section{DESIGN MIX}

5.1 The mix design of concrete is done based on properties of cement, Fine aggregate, coarse aggregate, Water. The mix proportion for concrete is obtained as $1: 1.5: 3$ and water cement ratio as 0.45 .

\section{TESTING METHODS}

\subsection{COMPRESSIVE STRENGTH}

The cube specimens were tested on compression testing machine of capacity $3000 \mathrm{KN}$. The bearing surface of machine was wiped off clean and sand or other material removed from the surface of the specimen. The specimen was placed in machine in such a manner that the load was applied to opposite sides of the cubes as casted that is, not top and bottom. The axis of the specimen was carefully aligned at the center of loading frame. The load applied was increased continuously at a constant rate until the resistance of the specimen to the increasing load breaks down and no longer can be sustained. The maximum load applied on specimen was recorded.

\section{$\mathbf{F c}=\mathbf{P} / \mathbf{A}$}

where, $\mathrm{P}$ is load \& $\mathrm{A}$ is area. Following graph shows the variation in compressive strength with addition of PEG.

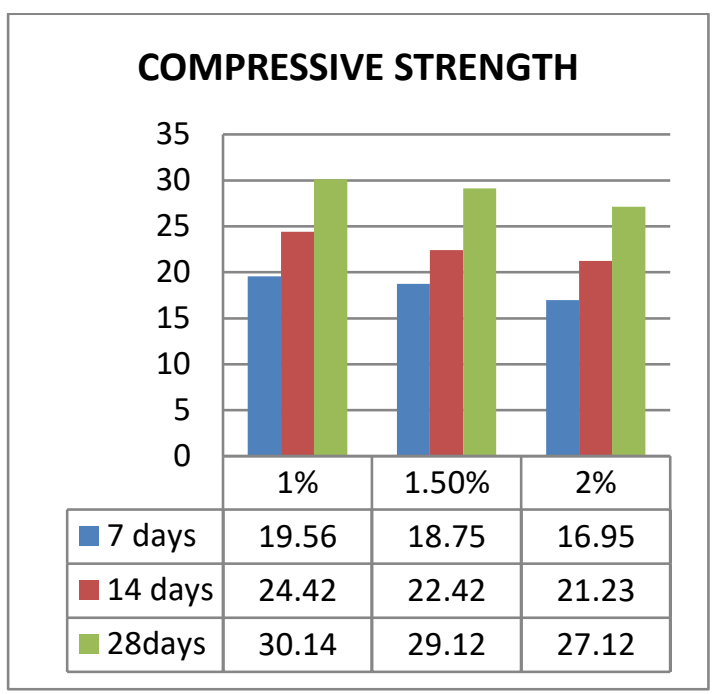

\subsection{SPLIT TENSILE STRENGTH}

The cylinder specimens were tested on compression testing machine of capacity $3000 \mathrm{KN}$. The bearing surface of machine was wiped off clean and looses other sand or other material removed from the surface of the specimen. The load applied was increased continuously at a constant rate until the resistance of the specimen to the increasing load breaks down and no longer can be sustained. The maximum load applied on specimen was recorded

\section{fsplit $=2 \mathrm{P} / \boldsymbol{\pi D}$,}

where $\mathrm{P}=$ load, $\mathrm{D}=$ diameter of cylinder, $\mathrm{L}=$ length of the cylinder. Following graph shows the variation of split tensile strength with addition of PEG. 


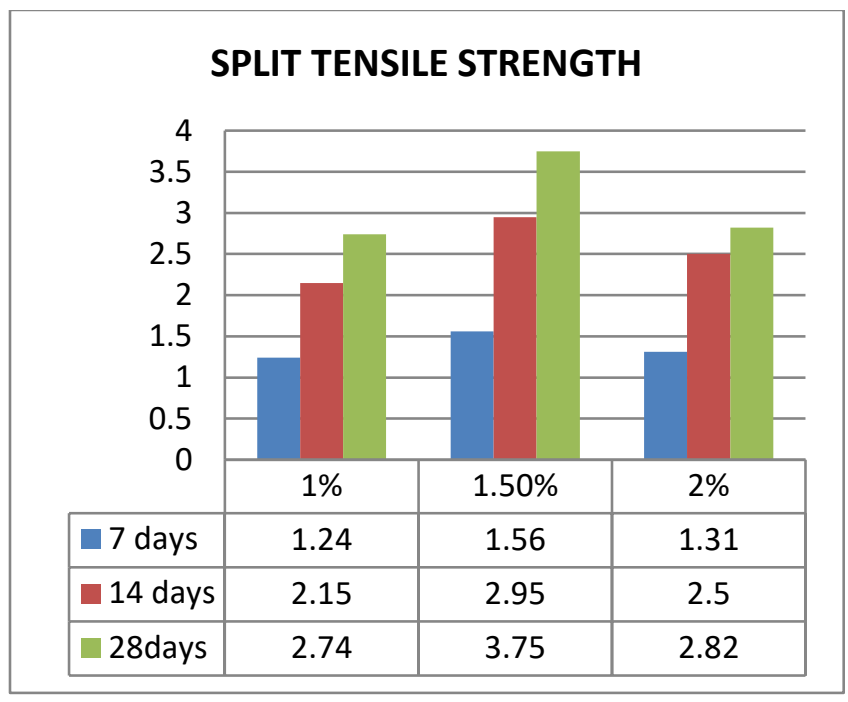

\subsection{FLEXURAL STREGTH}

The beam specimens were tested on universal testing machine for two-point loading to create a pure bending. The bearing surface of machine was wiped off clean and sand or other material is removed from the surface of the specimen. The two point bending load applied was increased continuously at a constant rate until the specimen breaks down and no longer can be sustained. The maximum load applied on specimen was recorded.

\section{f strength $=(\mathrm{WL}) /(\mathrm{bd} 2)$,}

Where, $\mathrm{W}=$ load at failure $\mathrm{L}=$ length of specimen $(700 \mathrm{~mm}) \mathrm{b}=$ width of specimen $(150 \mathrm{~mm}) \mathrm{d}=$ depth of specimen $(150 \mathrm{~mm})$

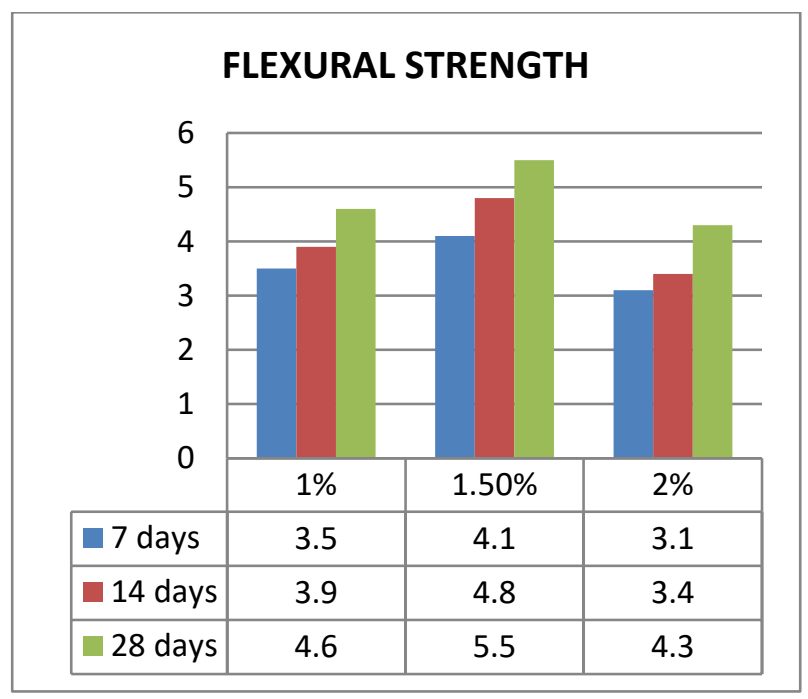

\section{CONCLUSION}

The optimum dosage of PEG400 for maximum strengths (compressive, tensile and modulus of rupture) was found to be $1.5 \%$

As percentage of PEG400 gets increased slump as well as compaction factor also gets increased.

Strength of self-curing concrete is relatively high when compared with conventional concrete.

Self-curing concrete is the viable answer to many problems faced due to lack of proper curing.

\section{REFERENCES}

[1] A Francis,J John, (2013), "Experimental Investigation On Mechanical Properties Of SelfCuring Concrete", International Journal of Emerging

[2] Cano Barrita, B.J. Balcom, T.W. Bremner, M.B. MacMillan, W.S. Langley "Moisture distribution in drying ordinary and High performance concrete cured in simulated hot dry climate", Kluwer academic Publishers October 2004.

[3] C. Selvamony, M.S. Ravikumar, S.U. Kannan and S. Basil Gnanappa, "Investigations on self-compacted self-curing concrete using limestone powder and clinkers", Vol.5, No.3 ARPN Journal of Engineering and Applied, 2010.

[4] Dhir, R.K., Hewlett, P.C., Lota, J.S., and Dyer, T.D.,(1996) "Influence of Microstructure on the Physical properties of SelfCuring Concrete," ACI Materials Journal,

[5] El-Dieb .A.S, "Self-curing concrete: Water retention, hydration and moisture transport", Construction and Building Materials 21 (2007), pp. 1282-1287.

[6] Hans W. Reinhardt and Silvia Weber, (1998), "SelfCured High Performance Concrete ", Journal Of Materials In Civil Engineering November 1998. 